\title{
Big Ideas: Annual Report 2013
}

Population Council

Follow this and additional works at: https://knowledgecommons.popcouncil.org/ series_newsletters_annualreports How does access to this work benefit you? Let us know!

\section{Recommended Citation}

"Big Ideas: Annual Report 2013." New York: Population Council, 2014. 


\section{Big Ideas}

For more than 60 years, the Population Council has addressed global health and development challenges by generating new ideas, creating and testing strategies, evaluating their impact, and delivering solutions.

Big ideas supported by evidence: It's our model for global change. 
President's Message

2

About the Population Council

8

\section{Highlights}

Renewing the dialogue on health and development policies in Pakistan 10

Continuing leadership on FP2020

Providing insights on HIV services for persons with disabilities

Developing the next generation of HIV-prevention products

Illuminating the lives of migrant adolescent girls

Financial report

Sources of support

Leadership

$\rightarrow$ On the cover The Council develops and evaluates initiatives to protect the health and lives of pregnant women, new mothers, and their babies.

$\rightarrow$ This page The Council's Biruh Tesfa program in Ethiopia reached more than 63,000 out-ofschool girls in the slums of Addis Ababa with HIV information, non-formal education, and links to health services. Girls enrolled in Biruh Tesfa were twice as likely as unenrolled girls to know how HIV is transmitted and where to get voluntary HIV counseling and testing, and to want to be tested. Now the Ethiopian government and local nongovernmental organizations are expanding the program nationally. 


\section{POPULATION}

COUNCIL

Ideas. Evidence. Impact.

popcouncil.org 


\section{Ideas. Evidence. Impact. \\ PETER J. DONALDSON}

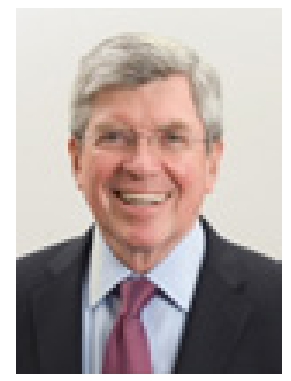

\section{It's our model for global change.}

"What matters is generating innovative ideas about how to improve health and advance development; gathering evidence; and delivering solutions that improve people's lives."
I recently passed the headquarters of Yakabox, a Frederick, Maryland, software company specializing in knowledge management. I was captivated by a sign in their second-floor window: "Do stuff that matters." For me, the sign describes the Population Council. We do stuff that matters. In the Council's case, what matters is generating innovative ideas about how to improve health and advance development; gathering evidence; and delivering solutions that improve people's lives.

I started my career with the Population Council in Bangkok in the summer of 1973, and at the end of 2014 I will retire.

When I first landed a position with the Council, I was overjoyed. I was a rookie on an all-star team of public health and social science experts who were changing the way the world thought about population, health, and development issues.

When I joined the Council, a staff member in Bangkok and several of his Thai colleagues had an idea about how to improve the delivery of family planning 
services. They believed that auxiliary nurse midwives could safely provide oral contraceptives. They launched a pilot program and gathered evidence, which supported their hypothesis. Their research transformed the delivery of reproductive health services in Thailand. Services at rural health centers were enhanced by the addition of auxiliary nurse midwives, and access to reproductive health care increased markedly. This innovation, now almost universally practiced, had its roots in Thailand's Ministry of Public Health and with a Population Council public health researcher.

We continue to offer innovative solutions to complex delivery system problems. We have studied the use of vouchers to increase access to health services and examined ways police departments can improve services for victims of gender-based violence.
In the 1970s, the average Thai woman had almost six children; her life expectancy was about 55 years. Today, female life expectancy is in the high 70s and fertility is below replacement. Maternal mortality has plummeted. Investments in children increased as family size declined; educational attainment skyrocketed; female labor force participation rose; and household income increased. A variety of factors caused these changes: sound government policies and their effective implementation, a successful private sector, strong markets, and dedicated nongovernmental organizations (NGOs). The Population Council played an important supporting role in this revolution.

There are many other examples in the Council's history of generating ideas, gathering evidence, and delivering impact. We are widely known for our contraceptive develop-

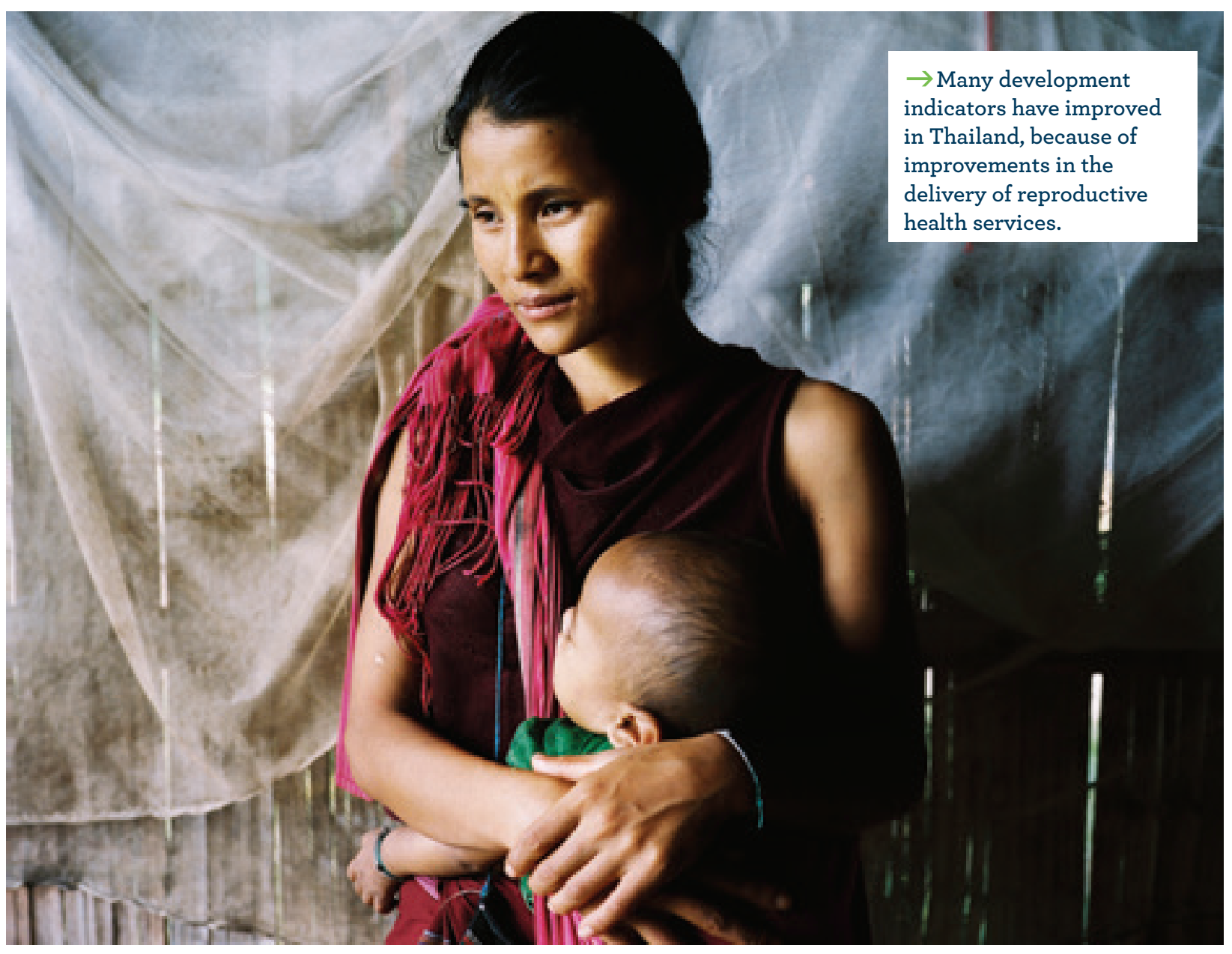




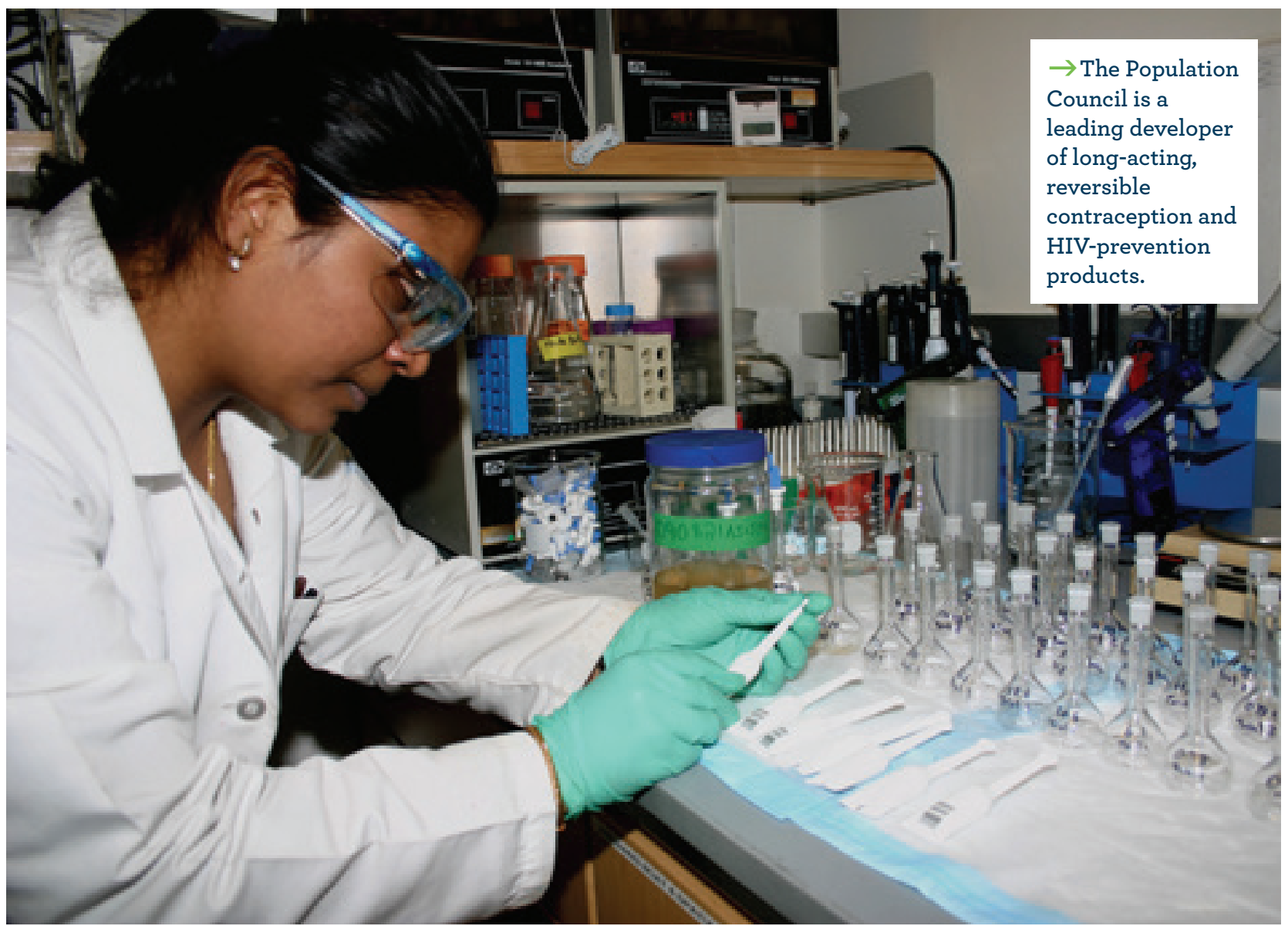

ment. Our biomedical labs have produced highly effective, long-acting, reversible contraceptives used by millions of women, including the Jadell ${ }^{\circledR}$ contraceptive implant and the Copper T IUD. Population Council Distinguished Scholar Anrudh Jain recently estimated the impact of Copper T use. He concluded that since 1988, when the device first became widely available, between 80 and 104 million devices have been used in developing countries, excluding China. He estimates these devices averted millions of unintended pregnancies and saved hundreds of thousands of mothers' lives.

Continuing in that tradition, we will soon submit a New Drug Application to the U.S. Food and Drug Administration for a one-year contraceptive vaginal ring. If approved, the ring will expand contraceptive choice, offering women a unique option for a long-acting, reversible contraceptive method that is under their control. We are also evaluating ways of making the provision of reproductive health and family planning services more equitable, comprehensive, and cost-effective.

Another important Council contribution is our work making the case for girls' programs. Until the 1990s, little was known about the health or the social and economic circumstances of girls in developing countries. Research on adolescence focused on premarital sex and pregnancy, but few policies or programs were designed to support girls. In the early 1990s, Council researchers began documenting the unique and typically overlooked needs of adolescent girls. We identified the factors that underpin adolescent girls' health and wellbeing and brought our findings to the attention of policymakers, program managers, and advocates. 


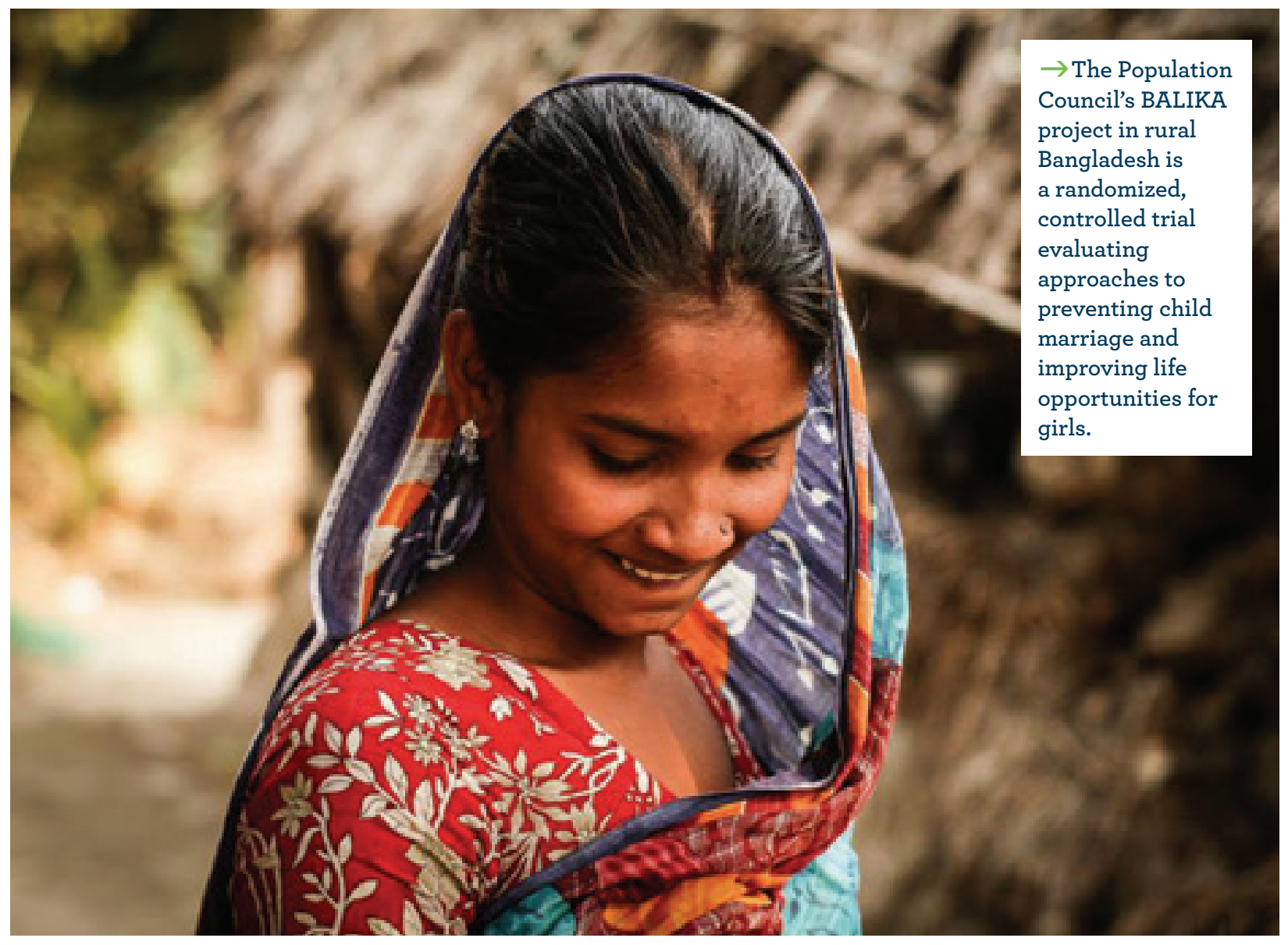

Our research has shaped the approach of many other organizations aimed at addressing girls' needs and ending child marriage. Early marriage is now a priority area for the United Nations Population Fund; our work set the stage for the World Bank's Adolescent Girls' Initiative. Successful Council programs for vulnerable adolescent girls are being brought to national scale by the Ethiopian government. Today, the Council supports the world's largest body of research on programs to improve the lives of adolescent girls in developing countries. We are studying ways to improve girls' lives in Bangladesh, Burkina Faso, Egypt, Ethiopia, Guatemala, India, Kenya, Nigeria, Tanzania, and Zambia, and advising governments and organizations in additional countries.
"In the early 1990s, Council

researchers began documenting the unique and typically

overlooked needs of adolescent girls. We tried to identify the factors that underpin health and wellbeing and then bring our findings to the attention of policymakers, program managers, and advocates." 


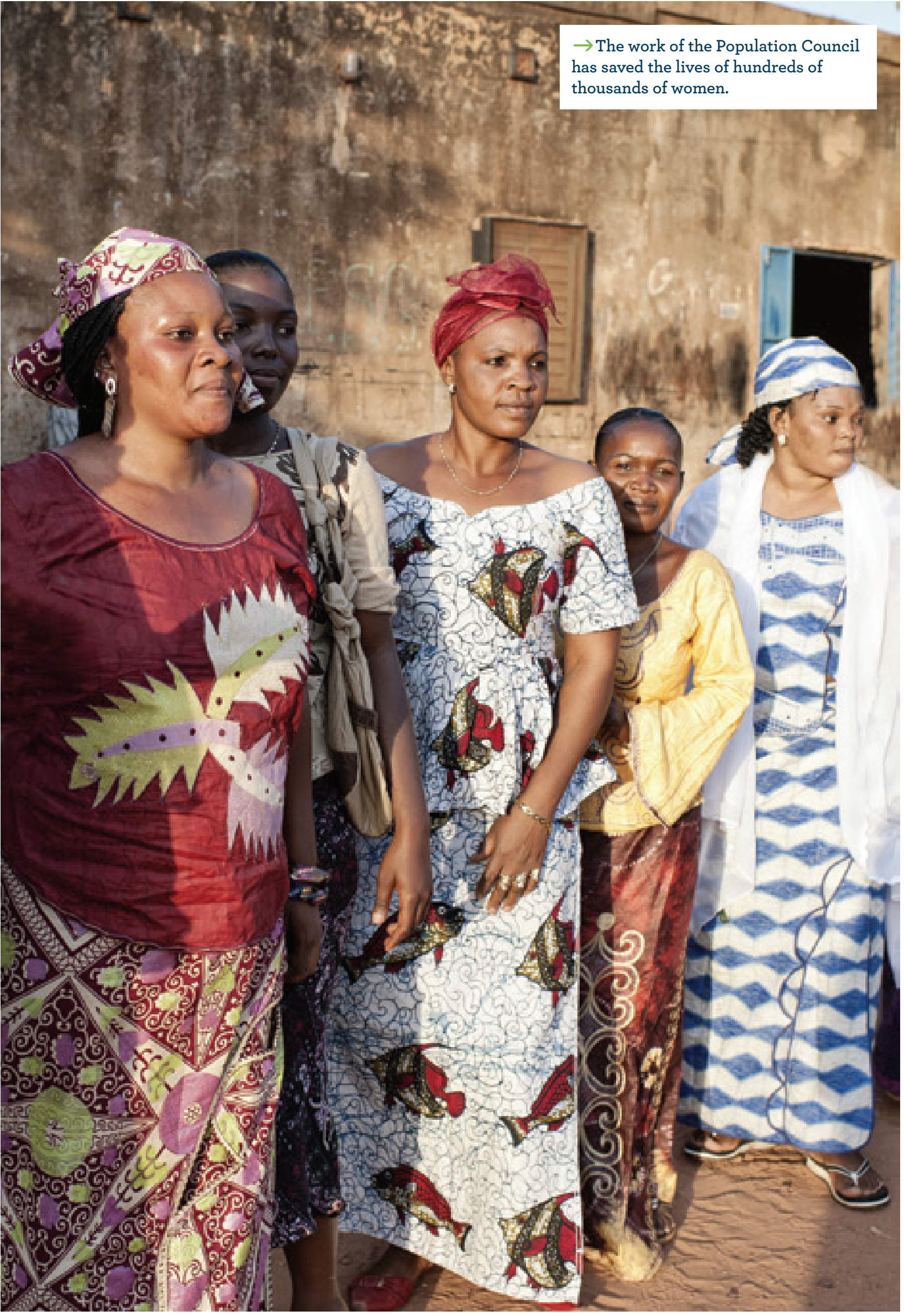


Lasting change is seldom triggered by a single study. Having an impact typically requires a substantial body of information and analysis. Impact requires close collaboration between researchers and policy and program partners. And immense dedication. For more than 60 years, the Council has worked around the world to generate ideas, gather evidence, and deliver solutions that have an impact.

We have been part of huge accomplishments since our founding, but challenges remain. For example, many countries have seen an emergence of conservative forces that want to limit basic human rights. A law passed recently in Nigeria prohibits gay and lesbian citizens from gathering and organizing. Uganda toughened penalties for homosexual behavior, already illegal in that country. Such laws jeopardize public health. They make it even harder to reach populations with the highest risk of HIV infection with prevention, care, and treatment services.

But we are determined. The Council was among the first organizations to document the size and HIV prevalence and incidence rates of populations in Africa with the highest risk of HIV. Our work in Kenya resulted in the first regional East African conference on the health needs of men who have sex with men, and we conducted the first study in India to document the sexual and drug-related HIV risks of people who inject drugs. Today, our work continues to fill knowledge gaps that compromise the success of HIV-prevention efforts and helps to inform international dialogue in ways that protect health and advance rights.
We are able to face challenges and make an impact because of the quality of our staff, the support of generous donors and dedicated trustees, and-most important-fruitful partnerships with governments and nongovernmental organizations around the world and with committed, thoughtful, energetic professionals who share our vision.

\section{"Our approach is to focus on what we do best: develop new ideas, collect evidence to evaluate our thinking, and work with partners to promote positive change."}

This annual report presents some of our recent successes and our plans for the future.

For 40 years I have been dazzled by the work that my colleagues and our partners have done and the way that work has helped change the world for the better. I enjoy my job very much, but great institutions benefit from leadership changes. After ten years at the helm of this organization, it is an apt time to pass the baton to the next generation.

As I prepare to leave, I am convinced that our work matters and has made a difference; we have improved health, saved lives, and advanced development.

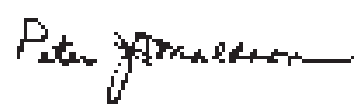

Peter J. Donaldson

President 


\section{The Population Council conducts research and delivers solutions to improve lives around the world.}

\section{$\rightarrow$ Tackling tough challenges}

The Population Council's Poverty, Gender, and Youth program seeks to understand and address the disparities in opportunity that arise during adolescence, the critical requirements for reaching a successful, productive adulthood, the causes and consequences of gender inequality, and the social dimensions of poverty in developing countries.

Our HIV and AIDS program is devoted to understanding and slowing the spread of the HIV epidemic. Through biomedical and behavioral research, we expand access to innovative and effective products and services, with a focus on the hardestto-reach, most marginalized populations.
Our Reproductive Health program strives to improve sexual and reproductive health, especially for vulnerable people in developing countries. We help individuals to achieve their family planning and reproductive health goals through improvements in technologies and services. We work to reduce maternal mortality and morbidity and to improve equity and quality in the delivery of care.

\section{Established in 1952, the} Population Council is governed by an international board of trustees. Its New York headquarters supports a global network of country offices. The Council staff consists of more than 575 women and men from over 30 countries. More than 60 percent work in our international offices. Council staff members conduct research and carry out programs in 50 countries.

\section{$\rightarrow$ Delivering solutions}

Population Council staff identify consequential health and development problems; work with developing-country partners to design, implement, and evaluate programs to address these challenges; conduct biomedical research to develop new contraceptives and microbicides; inform policymakers, program managers, the scientific , and the public about the results of our research; participate with governments and nongovernmental organizations to expand successful pilot programs and to improve large-scale programs; and collaborate with pharmaceutical companies to ensure that our products are available and affordable to the poorest and most vulnerable people worldwide. 


\section{$\rightarrow$ Sharing knowledge}

The Population Council publishes two widely read and influential peer-reviewed scientific journals: Population and Development Review and Studies in Family Planning. The Council also maintains a website and produces and disseminates books, working papers, newsletters, reports, slide shows, software, and toolkits. Search our research and publications at popcouncil.org/research.

\section{$\rightarrow$ Improving programs}

The Population Council's work does not end with conducting research. We strive to ensure that our findings are translated into concrete improvements in policies and programs. We provide technical assistance to strengthen national programs, and we offer expertise in ex- panding effective and sustain-

able interventions, implementing systems to monitor and evaluate projects, and finding innovative ways to pay for the costs of care.

\section{$\rightarrow$ Strengthening technical expertise}

The Population Council helps to improve the skills and knowledge of biomedical, public health, and social science researchers in developing countries through grants, fellowships, apprenticeships, and support to research centers. The Council's fellowship programs have helped advance the careers of thousands of social and biomedical scientists, public health researchers, and program managers, many of whom have gone on to hold leadership positions. In 2013 , we supported 25 fellows.

\section{$\rightarrow$ Forming partnerships}

Achieving our ambitious mission is only possible in partnership with governments, universities, foundations, pharmaceutical companies, public and private health networks, hospitals, research centers, nongovernmental organizations, and individuals from around the world. These partnerships represent one of the most influential ways in which we improve services and create lasting change. Through our partnerships, we support sound practices and efforts to increase the scope of highly effective programs. 


\section{Pakistan's future security and prosperity depend upon the health of its people and the country's ability to prepare its young and growing population for a global economy.}

\section{The Population Council published two influential reports that renewed dialogue and prompted action on vital health and development opportunities in Pakistan.}

$\rightarrow$ The Council and the United Nations Population Fund (UNFPA) published Capturing the Demographic Dividend in Pakistan, which calls for investments in education, particularly girls' primary education; family planning; and job creation to take advantage of a favorable population age structure and enhance economic growth. The report has been embraced by high-level policymakers, who have called for re-examining the population and development debate through the lens of the demographic dividend. $\rightarrow$ With the Guttmacher Institute, the Council released "Post-abortion care in Pakistan: A national study," which found that hundreds of thousands of abortion-related complications occur in that country each year. The report provided recommendations for improving post-abortion care, expanding access to high-quality and affordable family planning services, and building capacity among health care providers. The study was funded by the Research and Advocacy Fund, the UK Department for International Development, and the Australian Agency for International Development. 


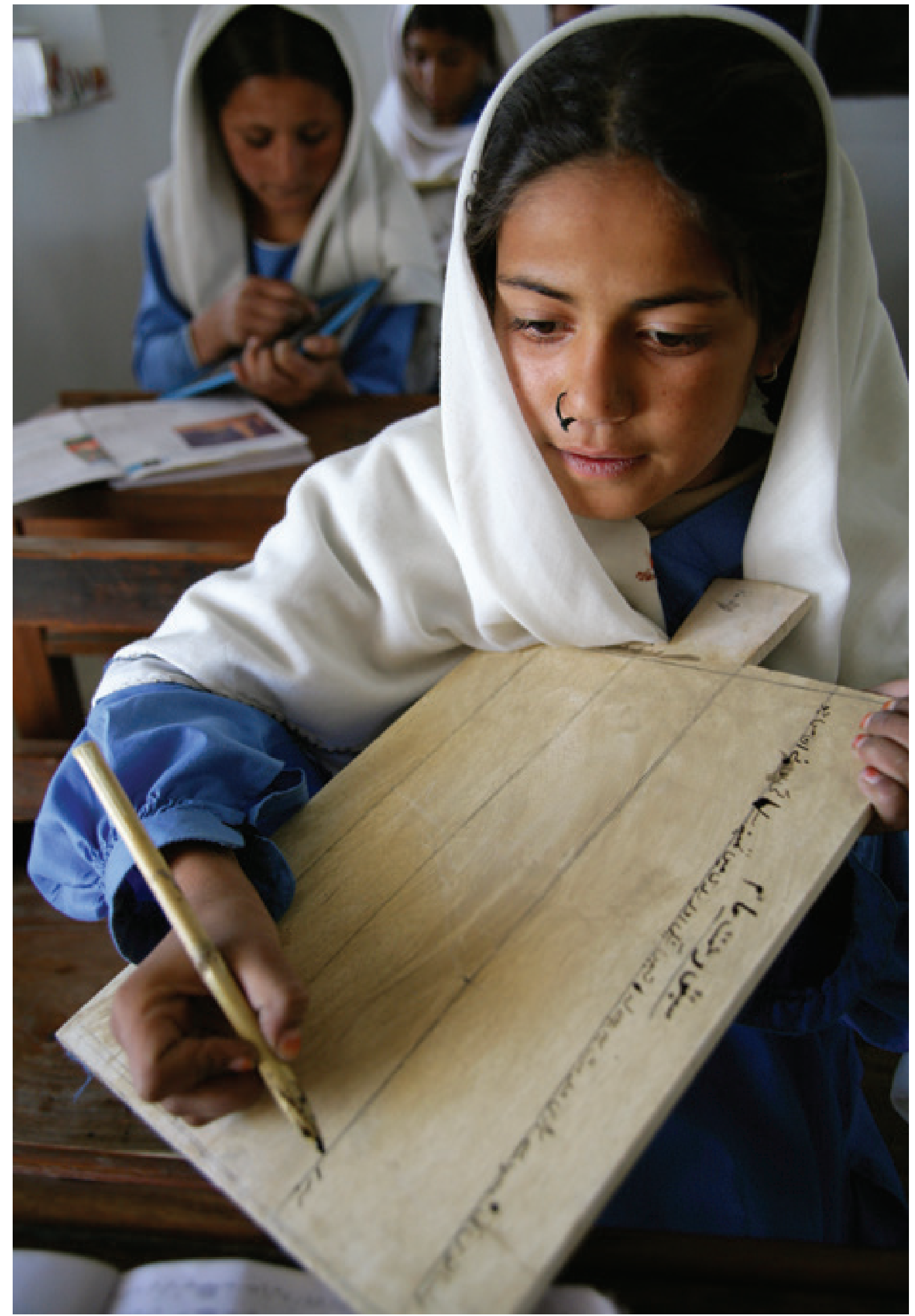




\section{New investments in family planning can improve health and increase economic opportunity for women and girls.}

\section{The Population Council continued its leadership in the global effort to provide 120 million more women and girls with access to voluntary family planning information, contraceptives, and services by 2020, known as FP2O2O.}

\begin{abstract}
$\rightarrow$ Intellectual leadership. The Council published The Unfinished Agenda to Meet FP2020 Goals: 12 Actions to Fill Critical Evidence Gaps, by Council researchers Ian Askew and Martha Brady. The book summarizes existing information and highlights areas where more evidence is needed to guide FP2020 efforts to increase contraceptive access and choice and improve equity.
\end{abstract}

POPCOUNCIL.ORG/ UPLOADS/PDFS/2013RH_ UNFINISHEDAGENDA.PDF $\rightarrow$ Leading and supporting FP2020 efforts.

At the International Conference on Family Planning in Addis Ababa, Ethiopia, the Council convened two high-level gatherings of donor governments, researchers, international health organizations, advocacy groups, and pharmaceutical companies to think creatively about the road forward for FP2020. Co-led by Zeba Sathar, Population Council Pakistan country director, the FP2020 Performance Monitoring and Accountability Working Group facilitates the collection, analysis, and use of the data needed to measure the progress of FP2020. The working group ensures accountability for implementing the financial, policy, and program commitments made by governments, donors, NGOs, and others. Many other Council professionals are also involved in supporting and ensuring the success of FP2020. 

(6)

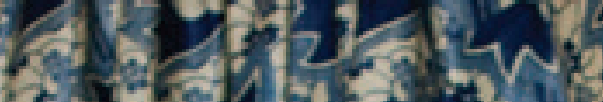

te 5 a de

s. $3=10 \mathrm{cos}$

mat sem 3

Existins

82501 ald

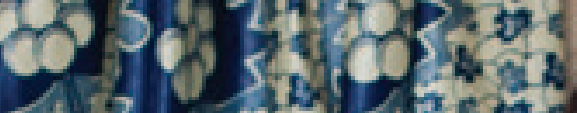

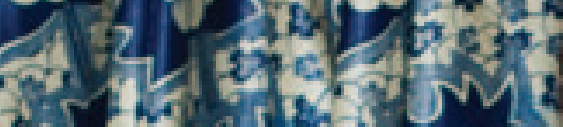

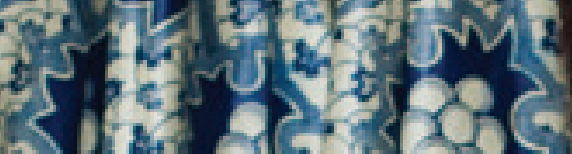

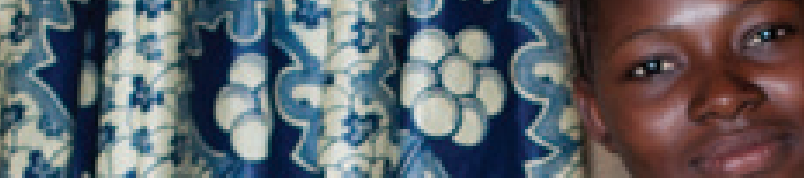

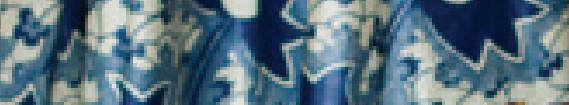

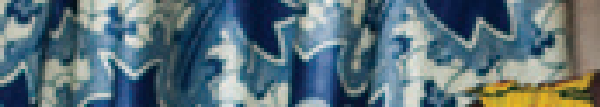

5 - 513 ins

2)

bif a y

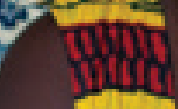

mint

8 ix $2 \times 1$ yeg OS:

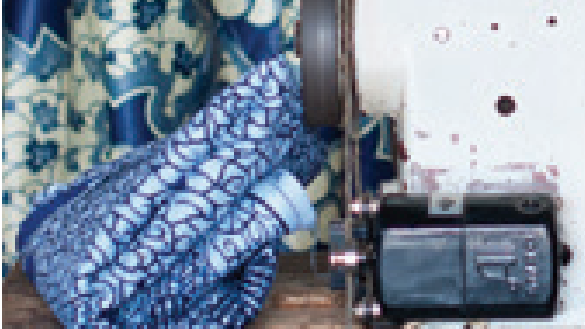

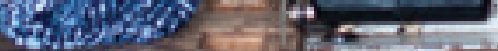
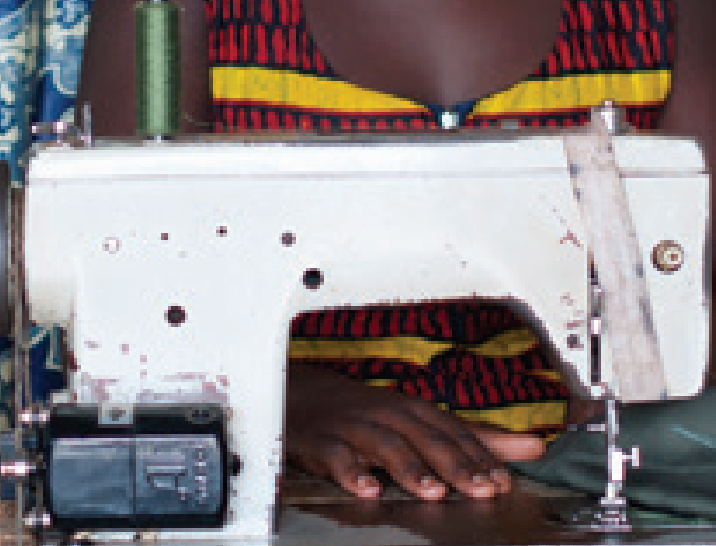

(C)

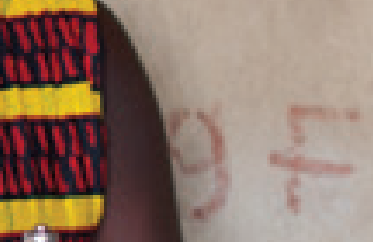

.

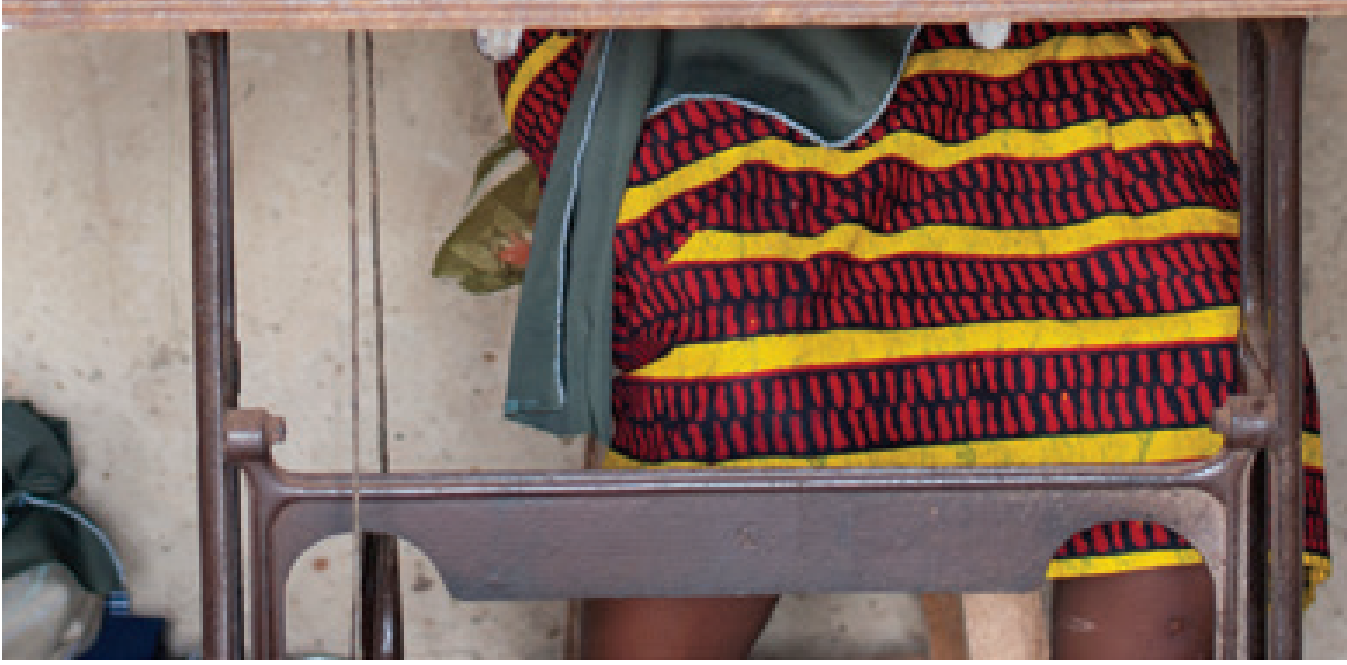




\section{Achieving an AIDS-free future requires addressing the HIV vulnerability of people with disabilities.}

\section{The Council-led HIVCore project} conducted one of the first investigations of HIV services for people with disabilities in Ghana, Uganda, and Zambia. The findings raised awareness among government policymakers and provided crucial evidence for program development and evaluation.

\footnotetext{
$\rightarrow$ Persons with disabilities experience greater sexual vulnerability to HIV. They are more frequently exposed to sexual abuse and-because they have fewer options for sexual partners-they often have sexual partners who pose a higher risk of HIV infection. Moreover, many people with disabilities have limited or no access to HIV prevention, care, and treatment services.

The Council-led, USAID-funded research found that access is limited by physical, transportation, and communication barriers, stigma toward persons with disabilities,
}

and lack of providers trained to work with people with disabilities. Many people with disabilities do not have access to condoms or do not know how to use them. Based on input collected in the research, efforts to raise awareness, address stigma, and make physical adaptations could increase access and reduce vulnerability.

HIVCORE.ORG/PUBS/ HIVCORENL_SEP2013.PDF 


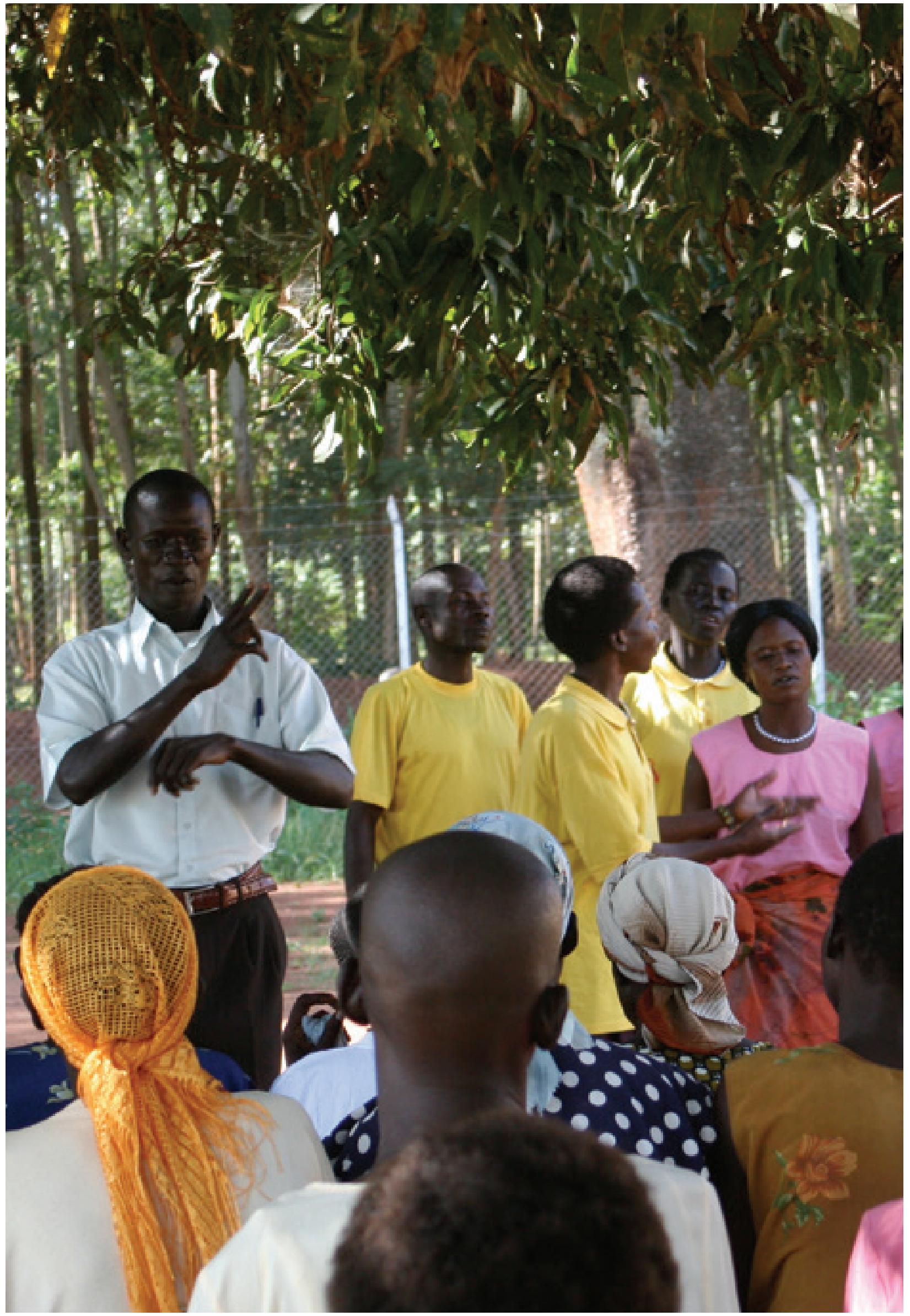




\section{Despite progress, nearly 6,300 people become infected with HIV every day- that's 262 every hour. New prevention methods are urgently needed.}

In 2013, the Population Council worked toward the goal of an AIDS-free future by continuing development of the next generation of HIV-prevention products and by conducting research to identify and overcome barriers to successful microbicide clinical trials.

\footnotetext{
$\rightarrow$ The Council is developing the next generation of microbicides-broadspectrum products used in the vagina or rectum to protect against HIV and other sexually transmitted infections. Using novel agents, the Council's microbicides-provided via gels, rings, and nanofiber-based delivery systems-will make vital contributions to global public health.
}

\author{
Several candidate microbicides have been \\ tested over the past two decades. Yet the \\ results of clinical trials have been largely \\ disappointing. One reason for this has little \\ to do with product efficacy; trial participants \\ may not be using products correctly and \\ consistently. Council researchers are \\ developing and testing strategies to support \\ correct use. A 2013 paper, co-authored by \\ the Council, presented the state of the art for \\ future trials, and for when microbicides are \\ available for general use.
}




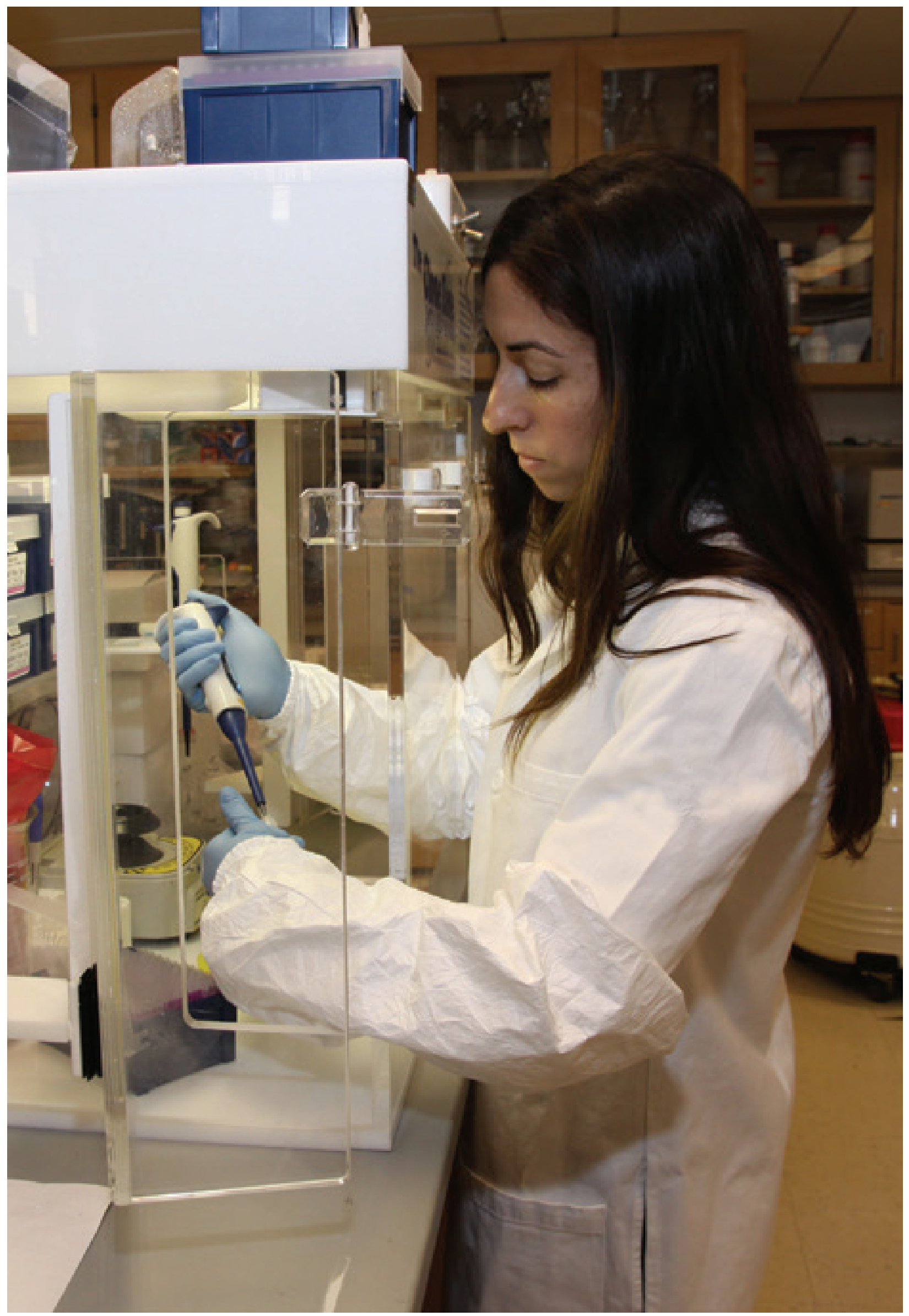




\section{The Population Council examined}

the social and economic

determinants of migration by

adolescent girls in developing

countries and identified the

links among migration, risk, and

opportunity.

We published our results in Girls

on the Move: Adolescent Girls \&

Migration in the Developing World, the first report of its kind.

\section{$\rightarrow$ Girls on the Move challenged conventional wisdom. We found that, while migration can be risky, for the majority of girls who migrate it can also lead to autonomy, opportunity, and economic stability-provided that necessary safety nets and resources are in place.}

The authors have presented their findings to the U.S. government, the European Union, the United Nations, and the World Bank.
The report, part of the Girls Count series (an initiative of the Coalition for Adolescent Girls), was named by the Guardian Global Development Professionals Network as one of five reports that "made a mark" for girls in 2013. Support for the report was provided by the Nike Foundation and the UN Foundation.

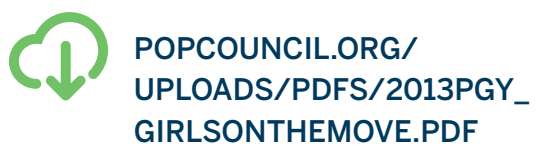




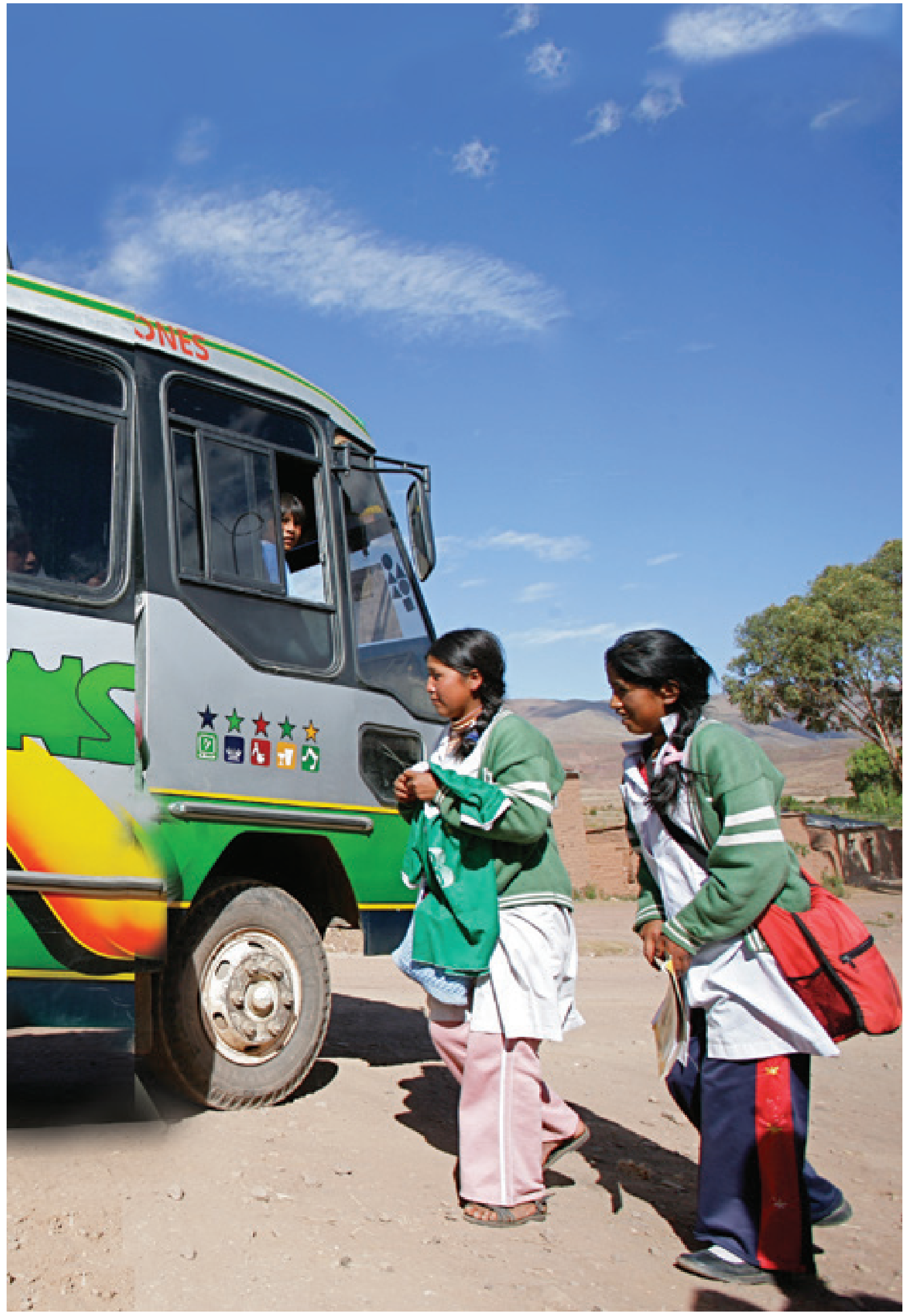


We are pleased to report that the Population Council's revenue increased by more than 31 percent, from $\$ 72.6$ million in 2012 to $\$ 95.3$ million in 2013 . This increase helps maintain the Council's financial health and ensures that we have the resources to continue our vital work.

The charts on this page provide details on the Council's sources of support and use of funds. The Council's program spending ratio, a key financial indicator, was 85 percent for fiscal 2013. For every dollar spent, 85 cents goes directly to research and program activities, demonstrating our prudent management and commitment to our mission.

We closely monitor the Council's financial status and remain committed to the fiscal discipline necessary to maintain our record of accomplishments. Readers interested in learning more about the Council's finances can consult http://popcouncil.org/who/financials.asp

\section{SOURCES OF SUPPORT \\ TOTAL \$95.3 MILLION}

Multilateral organizations 3\%

Other governments $12 \%$

Interest and dividends 3\%

Royalties 2\%

Investment returns 17\%

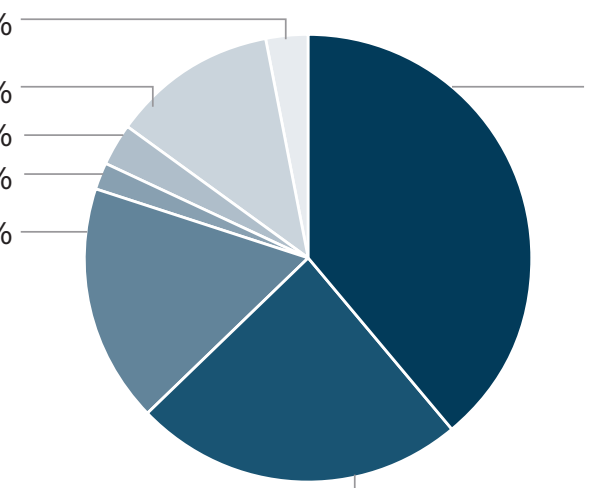

undations, corporations, nongovernmental organizations,

\section{USES OF FUNDS}

TOTAL \$87.2 MILLION

Fundraising $1 \%$

\section{Other program services $3 \%$ \\ Other program services $3 \%$}

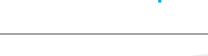

Management and general 14\%

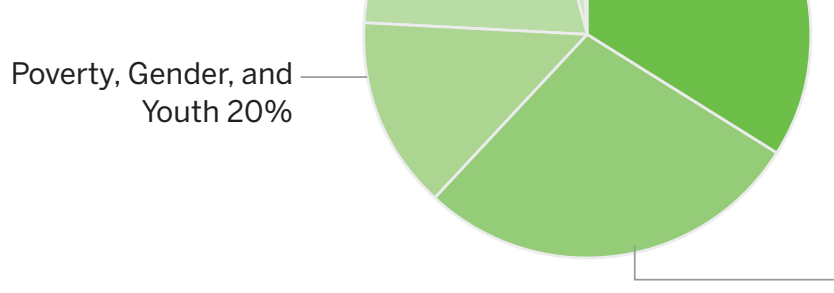

HIV and AIDS 28\% and individuals $24 \%$

U.S. government 39\%

Reproductive Health 34\% 


\begin{tabular}{|c|c|c|c|c|c|c|}
\hline & \multicolumn{3}{|c|}{ Unrestricted } & \multicolumn{2}{|c|}{ Restricted } & \multirow[b]{2}{*}{ Total } \\
\hline & $\begin{array}{r}\text { General } \\
\text { undesignated }\end{array}$ & $\begin{array}{l}\text { The John D. } \\
\text { Rockefeller 3rd } \\
\text { Memorial Fund } \\
\text { and others }\end{array}$ & Total & $\begin{array}{l}\text { Temporarily } \\
\text { restricted }\end{array}$ & $\begin{array}{l}\text { Permanently } \\
\text { restricted }\end{array}$ & \\
\hline \multicolumn{7}{|l|}{ OPERATING REVENUE } \\
\hline Grants and contributions & $\$ 72,985,551$ & 4,000 & $72,989,551$ & $1,830,494$ & - & $74,820,045$ \\
\hline Royalties & $2,234,709$ & - & $2,234,709$ & - & - & $2,234,709$ \\
\hline $\begin{array}{l}\text { Interest and dividends (net of } \\
\$ 188,459 \text { investment fees) }\end{array}$ & 4,033 & $1,997,320$ & $2,001,353$ & 419,293 & - & $2,420,646$ \\
\hline $\begin{array}{l}\text { Net appreciation (depreciation) } \\
\text { in fair value of investments }\end{array}$ & $(1,421)$ & $13,268,395$ & $13,266,974$ & $2,514,956$ & - & $15,781,930$ \\
\hline Other & 75,719 & - & 75,719 & - & - & 75,719 \\
\hline Net assets released from restrictions & $6,339,254$ & - & $6,339,254$ & $(6,339,254)$ & - & - \\
\hline TOTAL OPERATING REVENUE & $81,637,845$ & $15,269,715$ & $96,907,560$ & $(1,574,511)$ & - & $95,333,049$ \\
\hline \multicolumn{7}{|l|}{ OPERATING EXPENSES } \\
\hline \multicolumn{7}{|l|}{ Program services } \\
\hline HIV and AIDS & $24,744,460$ & - & $24,744,460$ & - & - & $24,744,460$ \\
\hline Poverty, Gender, and Youth & $17,630,651$ & 186,797 & $17,817,448$ & - & - & $17,817,448$ \\
\hline Reproductive Health & $28,683,054$ & 883,979 & $29,567,033$ & - & - & $29,567,033$ \\
\hline Distinguished Colleagues & 237,168 & - & 237,168 & - & - & 237,168 \\
\hline Publications & $1,636,905$ & - & $1,636,905$ & - & - & $1,636,905$ \\
\hline TOTAL PROGRAM SERVICES & $72,932,238$ & $1,070,776$ & $74,003,014$ & - & - & $74,003,014$ \\
\hline \multicolumn{7}{|l|}{ Supporting services } \\
\hline Management and general & $12,287,115$ & 324,856 & $12,611,971$ & - & - & $12,611,971$ \\
\hline Fundraising & 546,151 & - & 546,151 & - & - & 546,151 \\
\hline TOTAL SUPPORTING SERVICES & $12,833,266$ & 324,856 & $13,158,122$ & - & - & $13,158,122$ \\
\hline TOTAL OPERATING EXPENSES & $85,765,504$ & $1,395,632$ & $87,161,136$ & - & - & $87,161,136$ \\
\hline $\begin{array}{l}\text { (Deficiency) excess of operating } \\
\text { revenue over operating expenses }\end{array}$ & $(4,127,659)$ & $13,874,083$ & $9,746,424$ & $(1,574,511)$ & - & $8,171,913$ \\
\hline \multicolumn{7}{|l|}{ Other changes in net assets } \\
\hline $\begin{array}{l}\text { Gain on lease obligation and other, } \\
\text { net }\end{array}$ & 189,546 & - & 189,546 & - & - & 189,546 \\
\hline $\begin{array}{l}\text { Pension and other postretirement } \\
\text { charges other than net periodic } \\
\text { benefit cost }\end{array}$ & $1,896,638$ & - & $1,896,638$ & - & - & $1,896,638$ \\
\hline Transfer from endowments & $3,323,069$ & $(2,625,438)$ & 697,631 & $(697,631)$ & - & - \\
\hline $\begin{array}{l}\text { INCREASE (DECREASE) } \\
\text { IN NET ASSETS }\end{array}$ & $1,281,594$ & $11,248,645$ & $12,530,239$ & $(2,272,142)$ & - & $10,258,097$ \\
\hline $\begin{array}{l}\text { NET ASSETS AT BEGINNING } \\
\text { OF YEAR }\end{array}$ & $4,146,820$ & $74,015,933$ & $78,162,753$ & $15,500,163$ & $5,485,776$ & $99,148,692$ \\
\hline NET ASSETS AT END OF YEAR & $\$ 5,428,414$ & $85,264,578$ & $90,692,992$ & $13,228,021$ & $5,485,776$ & $109,406,789$ \\
\hline
\end{tabular}


TOTAL

\section{ASSETS}

Cash and cash equivalents

Grants and contributions receivable, net

U.S. government agencies

$5,441,378$

Other

Other receivables

Prepaid expenses and other assets

Postretirement medical benefits trust

Investments

$105,023,952$

Fixed assets, net

TOTAL ASSETS

\section{LIABILITIES AND NET ASSETS}

Liabilities

Accounts payable, accrued expenses, and other liabilities

$\$ 6,394,104$

Awards, contracts, and fellowships payable

Program advances

Deferred rent credit

Accrued lease obligation

Postretirement medical benefits payable

Net assets

Unrestricted

General undesignated

The John D. Rockefeller 3rd Memorial Fund and others

SUBTOTAL UNRESTRICTED

Restricted

Temporarily restricted

Permanently restricted 
The Population Council is grateful to each of our donors, whose generosity makes our work possible.

Funding for the Population Council's work was generously provided by government agencies, multilateral organizations, foundations, corporations, and individuals. We value our longstanding relationships with many of these donors and welcome the support from new ones. Their commitment allows the Council to deliver solutions to critical health and development challenges and improve lives.

\section{$\rightarrow$ GOVERNMENTS \\ AND GOVERNMENTAL AGENCIES \\ Government of Denmark \\ - Ministry of Foreign \\ Affairs of Denmark \\ Government of Kenya \\ - Ministry of Health \\ Government of the \\ Netherlands \\ - Embassy of the \\ Kingdom of the \\ Netherlands \\ Government of Norway \\ - Norwegian Agency \\ for Development Cooperation (NORAD)}

Government of Sweden

- Swedish International Development Cooperation Agency (SIDA)

- Swedish Ministry for Foreign Affairs

Government of the

United Kingdom

- Department for International Development (DFID)

Government of the

United States

- Agency for International Development (USAID)

- Centers for Disease Control and Prevention (CDC)

- National Institutes of Health (NIH)

Municipality of Guatemala City

\section{$\rightarrow$ MULTILATERAL ORGANIZATIONS}

Global Network of People Living with HIV/AIDS (GNP+)

International Consortium for Emergency Contraception (ICEC)

Joint United Nations

Programme on HIV/ AIDS (UNAIDS)

United Nations Children's
Fund (UNICEF)
United Nations
Foundation (UNF)
United Nations
Population Fund
(UNFPA)
UN Women
World Bank Group
World Health
Organization (WHO)

\section{$\rightarrow$ FOUNDATIONS/} CORPORATIONS/

\section{OTHER}

NONGOVERNMENTAL

ORGANIZATIONS

AIDS Foundation of Chicago (AFC)

Albert Einstein College of Medicine (AECOM)

Anonymous

Bayer Schering Pharma AG

Better World Fund

The Fred $\mathrm{H}$. Bixby

Foundation

Columbia University

Medical Center

Deutsche Gesellschaft für Internationale Zusammenarbeit $\mathrm{GmbH}$

The William H. Donner Foundation

Elton John AIDS Foundation

EngenderHealth

Equality Now

FHI 360

The Ford Foundation

H. B. Fuller Foundation

Futures Group International, LLC

Futures Institute

The Bill \& Melinda Gates Foundation

Girl Hub
Global Development Network (GDN)

Guttmacher Institute

Harvard School of Public Health

Health Decisions

The William and Flora

Hewlett Foundation

HRA Pharma

Human Dignity

Foundation

Fred Hutchinson Cancer

Research Center

Institute of Educational

Development, BRAC

University (IED-BRACU)

Institute of International

Education

icddr,b

International

Development Research

Centre (IDRC)

International Food Policy

Research Institute (IFPRI)

International HIV/AIDS Alliance

International Initiative for Impact Evaluation (3ie)

International Planned Parenthood Federation (IPPF)

International Rescue Committee (IRC)

IntraHealth

Jacobs Foundation

Henry M. Jackson

Foundation for the

Advancement of

Military Medicine

The Johns Hopkins University

London School of

Hygiene \& Tropical

Medicine (LSHTM)

The John D. and

Catherine T. MacArthur

Foundation

Magee-Women's
Research Institute and Foundation (MWRIF)

Marie Stopes

International (MSI)

Nestlé Egypt

New York University

(NYU)

Nike Foundation

NoVo Foundation

Oxford Policy

Management (OPM)

The David \& Lucile

Packard Foundation

PATH

Population Media Center (PMC)

Population Services International (PSI)

Project Concern International

Public Health Foundation of India (PHFI)

Research \& Advocacy Fund (RAF) of the British Council

Research Triangle Institute International (RTI)

Silatech

Social Impact, Inc

Society for Family Health (SFH)

Solutions for Innovative

Policies, Programs and

Technologies

Stanford University

Summit Foundation, Inc.

University of Alabama at Birmingham

University of California at San Diego

University of California at San Francisco

University of Connecticut Health Center

University Research Co., LLC

University of Tennessee

ViiV Healthcare 


\section{$\rightarrow$ INDIVIDUAL DONORS AND FAMILY FOUNDATIONS \\ John D. Rockefeller 3rd \\ Visionaries}

Anonymous (3)

Robert R. Andrews, Jr.

Avis and Clifford Barrus

Medical Foundation

Jerry and Diane

Cunningham*

Edlow Family Fund

Dr. Kyung Ja Kim*

F. M. Kirby Foundation*

Millstream Fund*

The Minneapolis Foundation

The Blanchette Hooker Rockefeller Fund*

President's Laureates

Anonymous (5)

Brian Arbogast and Valerie Tarico

D. Euan and Angelica Baird

Lyman B. Brainerd, Jr. Family Foundation*

Willard B. Brown

George P. and ChingChing Chen Cernada*

Lilly and John Combias

Peter J. and Nancy Donaldson

Estate of Mary H. Ebert

Gary and Kristin

Friedman

Alva Greenberg

Dr. and Mrs. Anrudh K. Jain

JJJ Charitable Foundation

Lloyd S. Levine

Elizabeth J. McCormack*

Ursula and Paul Ofman

Barbara and Gary Parish
Sukey N. Wagner*

Kate and Seymour Weingarten

Dr. Rena J. Zieve and Dr. Greg J. Kuperberg*

Council Champions

Anonymous (5)

Sandra D. and Ethan D. Alyea, Jr.*

Sandra P. and Lawrence Arnold*

Michael Baird

Milton Barber

John R. Bermingham*

Ann K. Blanc

Andrew M. Boas*

John and Zenaida

Bongaarts*

Caithness Foundation, Inc.

Matthew and Dawn Cooper

Mr. and Mrs. Lewis B.

Cullman

Paul Demeny

EcoTrust

Sophie Eitel

Employees Charity

Organization of

Northrop Grumman*

Andrea Eschen*

Rosemary Faulkner

Glen M. Feighery*

Gorlitz Foundation, Ltd.

David Grill

Barbara Grodd

Sheila Gudiswitz

Evan Guillemin

Angel Gurria and Lulu Quintana

Elizabeth A. Hallin

Vivien and David Hanson

Claire Higham and Rees D. Thomas
William W. Hildreth

Joel Hillhouse

Kenneth M. Jones

Wayne V. Krill*

George Krumme*

Joel Kurtzberg*

John P. McBride

Microsoft Giving

Campaign

John M. and Renate E. Mirsky

Samarendranath and Rekha Mitra*

Jacob Moskowitz

Mary Catherine Phinney

Marnie S. Pillsbury

Robert T. Porter*

Alison J. Renner*

Thomas L. Richie and

Diane Pascal*

Julie A. Robichaud*

David Rockefeller*

Betsy and John A. Rolls*

Naomi Rutenberg*

Select Equity Group, Inc.

James Simonds

Cherida Collins Smith*

Sidney Stern Memorial Trust

Sue S. Stewart*

Te-Hsiung Sun*

Judith C. and John Townsend*

Ramachandra Tummala

United Way of Rhode Island

Lucy R. Waletzky*

Jed Weissberg and Shelley Roth*

Oliver and Helen M. Wolcott*

Boniface Zaino*

Suzanne C. and Paul L. Zuzelo*
Council Innovators

Anonymous (7)

Rosalind S. Abernathy

Donald J. and Dena C. Abrams

Joel W. Ager*

Timothy S. and Anne M. Allen

Philip and Marjorie

Appleman

Enrique Robledo

Arnuncio

Shawky Badawy

Wendy Baldwin

Rachel G. Beck and Jeremy Naftel

Elspeth G. Bobbs

Douglas H. Borsom

Bridgewood Fieldwater Foundation*

Sierra H. Bright

Frederick and Jane Buckner

Michael D. Butler

Emily Carmany

Jeanne Clelland

J. Jarrett Clinton*

Community Foundation of Eastern Connecticut

Mercedes B. Concepción*

Roberto Cuca*

Matthew D. and Nancy Davis*

Stanley F. and Elizabeth G. Dole*

Thomas H. and Sheila D. Ebert

Ernst and Jan Epstein*

Chet Fagin

Philip L. and Barbara Ferro

Andrew L. Frey*

Marianne Gawain-Davis

Carey Goldberg 


\begin{tabular}{|c|c|c|}
\hline $\begin{array}{l}\text { Google Matching Gifts } \\
\text { Program }\end{array}$ & $\begin{array}{l}\text { Daniel LoCascio* } \\
\text { Joanne Lyman }\end{array}$ & $\begin{array}{l}\text { John K. and Elizabeth A. } \\
\text { Sullivan }\end{array}$ \\
\hline $\begin{array}{l}\text { William M. Grady and Karen } \\
\text { D. Tsuchiya* }\end{array}$ & $\begin{array}{l}\text { Roger and Isabel } \\
\text { Marchese }\end{array}$ & $\begin{array}{l}\text { Andrea Suska } \\
\text { John M. Taylor and }\end{array}$ \\
\hline Leslie Graham & Merck Partnership for & Takata Nagata \\
\hline The Gordon and Llura & Giving* & Ricardo Terrassa \\
\hline Gund Foundation & Ruth and Irwin Merkatz & Aija Thacher \\
\hline Guy Harris* & Stanley J. Mierzwa & Glenn R. Tilles \\
\hline Mary W. Heller* & Peter Miller & Harriet B. Todd* \\
\hline $\begin{array}{l}\text { Albert I. and Jolene C. } \\
\text { Hermalin }\end{array}$ & $\begin{array}{l}\text { Daniel Mishell, Jr. and } \\
\text { Carol Mishell* }\end{array}$ & $\begin{array}{l}\text { Jill Trescott } \\
\text { Jacob Turino }\end{array}$ \\
\hline Judith Herzfeld & Ann and William T. Naftel & UBS Financial Services \\
\hline Susan E. Hetherington & Charles B. Nam & Inc. \\
\hline John Hirschi & Barbara Nee & George Vacek \\
\hline Douglas W. and Barbara & Network For Good* & Jean Van Der Tak* \\
\hline $\begin{array}{l}\text { E. Holdridge } \\
\text { Catherine W. Houghton }\end{array}$ & $\begin{array}{l}\text { The Roger and Joyce } \\
\text { Nussbaum Foundation* }\end{array}$ & $\begin{array}{l}\text { Michael A. and Tammy } \\
\text { Vaughn }\end{array}$ \\
\hline Richard R. and Elizabeth & Joy and Vern O’Dell & Richard Weinberg \\
\hline Frederick V. Iffert* & $\begin{array}{l}\text { Robert H. and Jessie } \\
\text { Palmer }\end{array}$ & $\begin{array}{l}\text { Kim S. and Kathleen W. } \\
\text { Wennesland* }\end{array}$ \\
\hline Anna Irwin & Jane S. Pattie & Nancy Whitney \\
\hline John Jaschke & Daniel K. and Susan A. & Wichita Falls Area \\
\hline Monwhea Jeng & Paulien & Community \\
\hline Jeffrey Jensen & Edgar Peara* & Foundation* \\
\hline Richard S. Johnson and & Linda Pierce* & Barbara Yanni* \\
\hline May J. Reed* & David Porteous and Vicky & Alice M. Young \\
\hline Denis F. Johnston* & Smith & H. Neil Zimmerman* \\
\hline Elise F. Jones* & David M. and Ann & \\
\hline Carmen and Karl A. & Reynolds & \\
\hline Jungbluth* & Edward and Sharon & \\
\hline Deborah L. and Richard & Rubin & \\
\hline A. Keefe & Matthew Rutenberg* & \\
\hline $\begin{array}{l}\text { Dennis G. and Joanne G. } \\
\text { Keith* }\end{array}$ & $\begin{array}{l}\text { Michael Saks and Roselle } \\
\text { Wissler }\end{array}$ & \\
\hline Brian and Lisa King & Steven Schmitt* & \\
\hline Margaret A. Knoll & Jutta R. Scott* & \\
\hline $\begin{array}{l}\text { Linda and David Lakhdhir } \\
\text { Thomas A. Lehrer }\end{array}$ & $\begin{array}{l}\text { Robert L. and Elizabeth } \\
\text { H. Scott* }\end{array}$ & \\
\hline Margaret J. LeMaster & Marianne E. Selph* & $\begin{array}{l}\text { *Donors whose names are } \\
\text { followed by an asterisk have }\end{array}$ \\
\hline Susan H. Levine & Puneet Sood & contributed to the Population \\
\hline Katherine Lewis and & Karen Steel & $\begin{array}{l}\text { Council for at least five } \\
\text { consecutive years. }\end{array}$ \\
\hline Richard A. Chasman & Craig Stine & \\
\hline
\end{tabular}

We acknowledge

with gratitude that

each member of the

Population Council's

Board of Trustees

made a gift to

support the Council.
Guy Harris*

Mary W. Heller*

Albert I. and Jolene C.

Herzfeld

Susan $\mathrm{E}$. Hetherington

John Hirschi

E. Holdridge

Catherine W. Houghton

$$
\text { C. Howe }
$$

Frederick V. Iffert*

Anna Irwin

John Jaschke

Monwhea Jeng

$$
\text { May J. Reed* }
$$

Denis F. Johnston*

Jungbluth*

Deborah L. and Richard

Dennis G. and Joanne G. eith*

Linda and David Lakhdhir

as A Lehrer

Susan H. Levine

Richard A Chasman
Joanne Lyman
Roger and Isabe
Marchese

Merck Partnership for

Ruth and Irwin Merkatz

Stanley J. Mierzwa

Peter Miller

Daniel Mishell, Jr. and

Carol Mishell*

Ann and William T. Naftel

Charles B. Nam

Barbara Nee

Network For Good*

The Roger and Joyce

Nussbaum Foundation*

Joy and Vern O'Dell

Robert $\mathrm{H}$. and Jessie

Jane S. Pattie

Daniel K. and Susan A.

Edgar Peara*

Smith

David M. and Ann

Reynolds

dward and Sharon

Matthew Rutenberg*

Michael Saks and Roselle

Steven Schmitt*

Jutta R. Scott*

Robert L. and Elizabeth

$$
\text { H. Scott* }
$$

Marianne E. Selph*

Craig Stine

\footnotetext{
*Donors whose names are owed by an asterisk have Council for at least five consecutive years.
} 


\section{Board of Trustees}

Mark A. Walker

Chairman

Managing Director

Rothschild

London, United Kingdom

\section{Darcy Bradbury}

Managing Director

The D.E. Shaw Group

New York, New York

\section{Peter Brandt}

Stamford, Connecticut

\section{Peter J. Donaldson}

President

Population Council

New York, New York

\section{Wafaa El-Sadr}

Professor of Clinical Medicine and Epidemiology

Mailman School of Public Health

Columbia University

New York, New York

\section{Anna Glasier}

Honorary Professor

Department of Obstetrics and

Gynecology

University of Edinburgh

Edinburgh, United Kingdom
Victor Halberstadt

Professor of Public Sector Economics

University of Leiden

Netherlands

\section{Henry L. King}

Senior Counsel

Davis Polk \& Wardwell

New York, New York

\section{Charles D. Klein}

Managing Director

American Securities Capital

Partners, LLC

New York, New York

\section{Anna Mastroianni}

Professor of Law

University of Washington

School of Law

Seattle, Washington

\section{Cheikh Mbacké}

Independent Consultant

Dakar, Senegal

\section{Lauren A. Meserve}

Deputy Chief Investment Officer

Metropolitan Museum of Art

New York, New York

\section{Jotham Musinguzi}

Regional Director

Partners in Population and

Development

Africa Regional Office

Kampala, Uganda

\section{Anne R. Pebley}

Professor

Department of Community Health Sciences

School of Public Health

University of California, Los Angeles

Los Angeles, California

\section{Terry Peigh}

Senior Vice President, Managing Director

Interpublic Group of Companies

New York, New York

\section{K. Sujatha Rao}

New Delhi, India

Elizabeth Eder Zobel de Ayala

Chairman

Teach for the Philippines

Makati City, Philippines 
Peter J. Donaldson

President

Mar Aguilar

Director

International Support

Ann K. Blanc

Vice President and Director

Poverty, Gender, and Youth

Program

John Bongaarts

Vice President and

Distinguished Scholar

\section{Renee Richardson}

Chief Financial Officer and Treasurer
Naomi Rutenberg

Vice President and Director

HIV and AIDS Program

James E. Sailer

Vice President

Corporate Affairs Division

John W. Townsend

Vice President and Director

Reproductive Health Program

Patricia C. Vaughan

General Counsel and Secretary 


\section{$\rightarrow$ UNITED STATES}

Headquarters

Population Council

One Dag Hammarskjold Plaza

9th Floor

New York, NY 10017 USA

Tel +1212 3390500

Fax +12127556052

E-mail pubinfo@popcouncil.org

Center for Biomedical Research

Population Council

1230 York Avenue

New York, NY 10065 USA

Tel +1 2123278731

Fax +12123277678

E-mail biomed@popcouncil.org

Washington, DC

Population Council

4301 Connecticut Avenue, NW

Suite 280

Washington, DC 20008 USA

Tel +12022379400

Fax +12022378410

E-mail popcouncil@popcouncil.org

\section{$\rightarrow$ INTERNATIONAL}

Bangladesh

Population Council

House CES (B) 21

Road 118

Gulshan, Dhaka, Bangladesh

Tel +880-2-8821227

Fax $+880-2-8823127$

E-mail info.bangladesh@ popcouncil.org

\section{Burkina Faso}

Population Council

Cité An III/ 1er Etage Pharmacie de la Liberté

36 Avenue de la Liberté

Ouagadougou, Burkina Faso

Tel +226-50-31-12-42

Fax +226-50-31-12-46

E-mail info.burkinafaso@ popcouncil.org

Egypt

Population Council

59 Misr-Helwan

Agricultural Road

Maadi, Egypt

Tel +2022525 5967

Fax +202-2525-5962

E-mailinfo.wana@popcouncil.org
Ethiopia

Population Council

Heritage Plaza, 4th Floor

Bole Medhaneialem Road

Addis Ababa, Ethiopia

Tel +251-11-663-17 12

Fax +251-11-663-1722

E-mailinfo.ethiopia@ popcouncil.org

\section{Ghana}

Population Council

14B Ridge Road behind MedLab Bldg.

Roman Ridge

Accra, Ghana

Tel +233-21-780711

Fax +233-21-780713

E-mail info.ghana@popcouncil.org

Guatemala

Population Council

23 Avenida 3-45

Zona 15, Vista Hermosa 1

Guatemala City, Guatemala

01015

Main tel +502 23692760

Alternate tel +50252930030

Fax +50223692760

E-mail info.guatemala@ popcouncil.org

India

Population Council

Zone 5A, Ground Floor

India Habitat Centre, Lodi Road

New Delhi, India 110003

Tel +91-11-2464-2901

Fax +91-11-2464-2903

E-mail info.india@popcouncil.org

Kenya

Population Council

General Accident House

Ralph Bunche Road

Nairobi, Kenya

Tel +254-20-2713-480

Fax +254-20-2713-479

E-mail info.nairobi@popcouncil.org

Mexico

Population Council

Avenida Cuauhtémoc no. 1400

Colonia Santa Cruz Atoyac

Delegación Benito Juárez

Mexico, DF

Mexico CP 03310

Tel +52-55-5658-1138

E-mail info.mexico@popcouncil.org
Nigeria

Population Council

Bassan Plaza, Block B, 3rd Floor

Plot 759, Central Business District; Off Herbert Macaulay Way

Abuja, Nigeria

Tel +234-9-8706071

E-mail info.nigeria@popcouncil.org

\section{Pakistan}

Population Council

House No. 7

Street No. 62 Sector F-6/3

Islamabad, Pakistan

Tel +(92-51) 8445566

Fax +(92-51) 2821401

E-mail info.pakistan@ popcouncil.org

\section{Senegal}

Population Council

Sacré Coeur Pyrotechnie

Appartement 2ème Etage à Droite

Dakar, Ponty

Senegal 21027

Tel +221338595300

Fax +221-33-824-1998

E-mail info.senegal@popcouncil.org

\section{South Africa}

Population Council

22 Lonehill Blvd Block B

Lonehill Office Park, Fourways

Johannesburg, South Africa 2062

Main tel +27 117817590

Alternate tel +27 117817594

Fax +27 113261483

E-mail info.joburg@popcouncil.org

Zambia

Population Council

Plot \#3670 No. 4 Mwaleshi Road

Olympic Park

Lusaka, Zambia 10101

Main tel +260 211295925

Fax +260 211295925

E-mail info.zambia@popcouncil.org 
The Population Council confronts critical health and development issues-from stopping the spread of HIV to improving reproductive health and ensuring that young people lead full and productive lives. Through biomedical, social science, and public health research in 50 countries, we work with our partners to deliver solutions that lead to more effective policies, programs, and technologies that improve lives around the world. Established in 1952 and headquartered in New York, the Council is a nongovernmental, nonprofit organization governed by an international board of trustees.

\section{popcouncil.org}

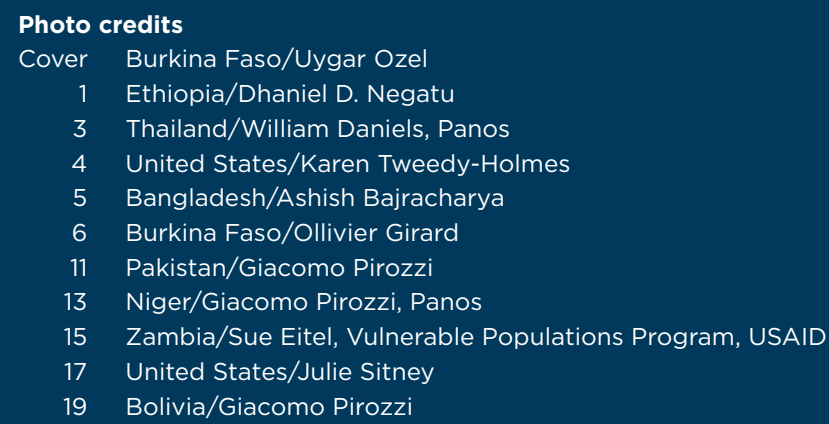




\section{POPULATION}

COUNCIL

Ideas. Evidence. Impact.

popcouncil.org 


\section{The pages that follow present lists of the Population Council's advisory and collaborative bodies, partners, and fellows.}




\section{POPULATION COUNCIL ADVISORY AND COLLABORATIVE BODIES}

\section{INSTITUTIONAL REVIEW BOARD}

Policymakers, program managers, and others concerned with population, reproductive health, and development turn to the Population Council for its rigorous research results that improve people's lives.

In its research, the Population Council aspires to the highest professional and ethical standards and has earned a worldwide reputation for excellence and integrity.

The Council requires that all studies (unless exempt) involving human subjects be reviewed by its Institutional Review Board (IRB) before research is initiated. The purpose of this review is to ensure that appropriate steps are taken to protect the rights and welfare of the individuals who participate as subjects in a study.

All Council investigators involved in studies that are reviewed by its IRB must provide proof of completion of a recent, approved ethical training course.

The Council's IRB has 13 members, whose expertise includes bioethics, biomedical engineering, demography, health care, HIV and AIDS, international relations, law, obstetrics/gynecology, physiology, public policy, regulatory affairs, and social psychology. It meets six times per year.

\section{John Bongaarts \\ Chairman \\ Population Council}

Arthur Allen

Saratoga Springs, New York

Machelle Allen

Bellevue Hospital Center

Andrew Davidson

Columbia University

Judith A. Diers

UNICEF

Ruth L. Fischbach

Columbia University

Kelly Hallman

Population Council
Victor Paulus, Delegate

Population Council

Rachael N. Pine

Legal Momentum

Saumya RamaRao

Population Council

June Reidenberg

Scarsdale, New York

Katie D. Schenk

Washington, DC

Charlotte Warren

Population Council 


\section{INTERNATIONAL COMMITTEE FOR CONTRACEPTION RESEARCH}

The International Committee for Contraception Research (ICCR), established by the Population Council in 1970, is a network of distinguished scientists and clinical investigators whose goal is to improve female and male reproductive and sexual health worldwide through the development of new concepts of contraception and reproductive medicine and the widespread application of contraceptive technologies.

The members advise the Council on new research areas and conduct clinical trials to test the safety, efficacy, and acceptability of Council-developed products.

Members of the ICCR and their staffs at cooperating universities and clinics work closely with staff at the Population Council's Center for Biomedical Research in design of delivery systems, prototypes, and clinical protocols for products under development. The clinics are selected for their commitment to reproductive health care and their expertise in the conduct of clinical trials involving contraceptive products.

The ICCR collaborates with Population Council staff members and with researchers at the World Health Organization, Family Health International, the National Institutes of Health, and the National Research Councils of the various countries in which ICCR members reside.

\section{Régine L. Sitruk-Ware \\ Chairperson \\ Population Council}

\section{Philippe Bouchard}

Hôpital Saint-Antoine, Paris University,

France

Vivian Brache

PROFAMILIA, Dominican Republic

William J. Bremner

University of Washington, Seattle

\section{Linan Cheng}

Shanghai Institute of Planned Parenthood

Research

lan Stewart Fraser

University of Sydney, Australia

\section{Kristina Gemzell-Danielsson}

Karolinska Institute, Sweden

Anna Glasier

University of Edinburgh

Edinburgh, United Kingdom

Jeffrey Jensen

Oregon Health and Science University

Daniel R. Mishell, Jr.

University of Southern California

Malabika Roy

Indian Council of Medical Research, India

Christina Wang

Harbor-UCLA Medical Center 


\section{POPULATION COUNCIL PARTNERS}

The Population Council collaborates with government agencies, universities, hospitals, research centers, nongovernmental and faith-based organizations, corporations, multilateral groups, and individuals in both developing and developed countries.

The following is a list of 2013 awards and contracts made by the Population Council. Collaboration with these partners and many others is a primary means through which the Council conducts research, implements programs, transfers technology, and strengthens institutional capacity.

\section{AFRICA}

\section{Benin}

Young Women's Christian Association of Benin, Cotonou

\section{Burkina Faso}

Association d'Appui et d'Eveil Pugsada, Ougadougou

Association KASABATI, Ouagadougou

Association Munyu es Femmes de la Comme, Banfora

Association SOS Jeunesse et Defis, Ouagadougou

Association TIE, Bobo-Dioulasso

Convention pour la Culture de la Paix, Ouagadougou

Young Women's Christian Association of Burkina Faso, Ouagadougou

\section{Egypt}

Assiut University, Assiut

Central Agency for Mobilization and Statistics, Cairo

Family and Environment Development Association, Qena

Foundation for Enlightenment on Development. Fayoum

Women's Association for Health Improvement, Sohag

\section{Ethiopia}

Hiwot Ethiopia, Addis Ababa

Organization for Prevention, Rehabilitation and Integration of Female Street Children, Addis Ababa

\section{Ghana}

Ghana Health Service, Ashanti Region

- Offinso Municipal District

- Offinso North District

- Sekyere Afram Plains District

- Mampong Municipal District

- Ejura Sekyeredumase District

- Ahafo Ano North District

- Ahafo Ano South District

- Bosomtwe Municipal District

- Bosome Freho District

- Asante Akim South District 
- Kwabre East District

- Sekyere Central District

- Sekyere South District

- Kumasi Metro District

- Amansie Central District

- Atwima Kwanwoma District

- Atwima Nwabiagya District

- Adansi South District

- Sekyere East District

- Ejisu-Juaben Municipal District

- Afigya Kwabre District

Ghana Health Service, Eastern Region

- Lower Manya Krobo District

- Yilo krobo District

- East Akim District

- Suhum Kraboa Coaltar District

- Fanteakwa District

- Kwahu East District

- Kwahu West District

- Kwahu North District

- Kwahu South District

- Akyemansa District

- Asuogyaman District

- Atiwa District

- Birim North District

- West Akim District

\section{Kenya}

African Population and Health Research Center, Nairobi Federation of Women Lawyers-Kenya, Nairobi Integrated Education for Community Empowerment, Nairobi KMET, Kisumu

Liverpool VCT Care and Treatment, Nairobi Moi University Faculty of Health Sciences, Eldoret MicroSave Consulting, Ltd., Nairobi National Nurses Association of Kenya, Nairobi REPACTED Kenya, Nakuru WEM Integrated Health Systems, Thika Young Women's Christian Association of Kenya, Nairobi

\section{Malawi}

Malawi Human Rights Resource Centre (MHRRC), Lilongwe

\section{Nigeria}

Population and Reproductive Health Initiative, Shika-Zaria 


\section{Senegal}

Laboratoire de Recherche sur les Transformations Economiques et Sociales, Dakar

\section{South Africa}

Solutions for Innovative Policies, Programs and Technologies, Johannesburg

Thohoyandou Victim Empowerment Programme (TVEP), Sibasa

\section{Swaziland}

Swaziland Action Group Against Abuse, Manzini

\section{Tanzania}

East, Central and Southern Africa Health Community, Arusha

Ifakara Health Institute, Dar es Salaam

Tabora Development Foundation Trust, Tabora

TAMASHA Company, Ltd., Arusha

\section{Uganda}

The AIDS Support Organization, Kampala

Child Helath and Development Center, Kampala

Jenga Community Development Outreach, Mbale

Kitovu Mobile AIDS Organization, Masaka

Youth Alive Uganda, Jinja

\section{Zambia}

Kawama Widows and Orphans Project, Ndola

Mitengo Women Association, Chongwe

National Savings and Credit Bank of Zambia, Lusaka

Vulnerable Orphans and Widows Association, Ndola

Young Women's Christian Association of Zambia, Mongu

\section{Zimbabwe}

Child Protection Society, Harare

Zimbabwe AIDS Prevention Project, Harare 


\section{THE AMERICAS}

\section{Dominican Republic}

Asociación Dominicana Pro-Bienestar de la Familia (PROFAMILIA), Santo Domingo

\section{Guatemala}

Fundacion Voces Vitales, Guatemala City

Instancia por las Salud y el Desarrollo de las Mujeres, Guatemala City

\section{Mexico}

Federacion Mexicana de Asociaciones Privadas (FEMAP), Cd. Juarez

\section{United States}

AIDS Healthcare Foundation, L.A., CA

Albert Einstein College of Medicine of Yeshiva University, Bronx, NY

Amani Global Works, New York, NY

Asante Africa Foundation, Livermore, CA

Clinton Health Access Initiative, Inc., Boston, MA

e-Health and Information Systems Nigeria, Santa Ana, CA

Elizabeth Glaser Pediatric AIDS Foundation, Washington, DC

Family Health International, Durham, NC

Futures Group International, Washington, DC

Gobee Group LLC, Bellevue, WA

Guttmacher Institute, New York, NY

Health Alliance International, Seattle, WA

Icahn School of Medicine at Mount Sinai, New York, NY

InSTEDD, Palo Alto, CA

International Planned Parenthood Federation/Western Hemisphere Region, New York, NY

Invest in Knowledge Initiative, Jamaica Plain, MA

Kijani Consulting LLC, Chapel Hill, NC

Los Angeles Biomedical Research Institute at Harbor-UCLA Medical Center, Los Angeles, CA

Lwala Community Alliance, Nashville, TN

Making Cents International, Washington, DC

Management Sciences for Health, Inc., Cambridge, MA

Population Reference Bureau, Washington, DC

Program for Appropriate Technology in Health, Seattle, WA

Project Concern International, San Diego, CA

Regenstrief Institute, Indianapolis, IN

Regents of the University of California, San Francisco Campus, San Francisco, CA

Tulane University, New Orleans, LA

University of Southern California, Los Angeles, CA

University of Washington, Seattle, WA

University of Wisconsin, Madison, WI 
ASIA

\section{Australia}

The Macfarlane Burnet Institute for Medical Research and Public Health LTD, Victoria

\section{Bangladesh}

International Centre for Diarrhoeal Disease Research, Bangladesh, Dhaka

mPower Social Enterprises, Ltd., Dhaka

Obstetrical and Gynecological Society of Bangladesh, Dhaka

Partners in Population and Development, Dhaka

Population and Services Training Center, Dhaka

\section{Cambodia}

Center for Advanced Studies, Phnom Penh

National Institute of Public Health, Phnom Penh

\section{India}

$\mathrm{CBCl}$ Society for Medical Education, Bangalore

Centre for Development and Population Activities, New Delhi

Institute of Economic Growth, Delhi

M. Venkatarangalya Foundation, Secunderabad,

National AIDS Research Institute, Pune

National Institute of Medical Statistics, New Delhi

Nehru Foundation for Development, Gujarat

Sahara Centre for Residential Care and Rehabilitation, New Delhi

Tata Institute of Social Sciences, Maharashtra

Tathapi Trust, Pune

\section{Nepal}

Center for Research on Environmental and Population Activities, Lalitpur

\section{Pakistan}

National Committee for Maternal and Neonatal Health, Karachi 


\section{EUROPE}

\section{France}

French National Institute for Health and Medical Research (INSERM), Paris

\section{Netherlands}

Stichting KU Radboud Universiteit, Najmegen

\section{Switzerland}

University of Zurich, Zurich

\section{United Kingdom}

CfBT Education Trust, Reading

International Planned Parenthood Federation, London

London School of Hygiene and Tropical Medicine, London

Marie Stopes International, London

RETRAK Ethiopia, Cheshire 


\section{POPULATION COUNCIL FELLOWS}

Population Council fellowships have helped advance the careers of social and biomedical scientists, public health researchers, and program managers throughout the world. In addition, a generous $\$ 5$ million grant from The Fred H. Bixby Foundation enables the Council to offer fellowships to young professionals, primarily from developing countries, in preparation for leadership in the fields of population, health, and development. The following is a list of 2013 Population Council fellows.

\section{BIOMEDICAL FELLOWS}

Fellows conduct research at the Center for Biomedical Research. Institutions listed are those with which fellows were affiliated before joining the Council.

Diana Goode, Postdoctoral fellow, Johns Hopkins School of Medicine

Yongmei Huang, Postdoctoral fellow, Shanghai Institute of Family Planning

Ryoei Hara, Postdoctoral fellow, Kawasaki Medical School

Kai Wai Mok, Predoctoral fellow, University of Hong Kong

Elizabeth Tang, Postdoctoral fellow, University of Hong Kong

Nan Li, Postdoctoral fellow, Hong Kong Baptist University

Natalia Guerra Perez, Postdoctoral fellow, Mount Sinai, College of Medicine

Hin Ting Wan, Predoctoral fellow, Hong Kong Baptist University

Xiang Xiao, Predoctoral fellow, University of Hong Kong

Sebastian Jarl, Predoctoral fellow, Linkoping University

Magnus Hallor, Predoctoral fellow, Linkoping University

Kristina Noring, Predoctoral fellow, Lunds University, School of Medicine

Annika Voigt, Predoctoral fellow, Lunds University, School of Medicine

Nazli Ece Ordueri, Postdoctoral fellow, Akeneiz University 


\section{FRED H. BIXBY FELLOWSHIP PROGRAM}

The Fred H. Bixby Fellowship Program offers expanded training opportunities for early-career population specialists and biomedical researchers from developing countries. Bixby fellows work with experienced mentors in the Population Council's network of offices, across the three program divisions.

\section{Africa}

\section{Côte d'Ivoire}

Louise Outtara. Impact of zinc in the mucosa during vaginal HIV/SIV transmission (Population Council, Center for Biomedical Research)

\section{Egypt}

Irene Selwaness. Study youth transition to adulthood, job quality and access to social protection in Egypt (Population Council, Cairo)

\section{Ghana}

Pearl Kyei. Analyze Iongitudinal data from the Malawi Schooling and Adolescents Survey (MSAS) (Population Council, New York)

Deladem Kusi-Appouh. To collaborate on the Safe Spaces, Financial Education and Savings for Adolescent Girls Program (Population Council, Zambia)

\section{Kenya}

Sam Wangila Wafula, To participate in the implementation and assessment of the RH Voucher program and Baby Monitor Project (Population Council, Kenya)

Eliud Wekesa, To study SRH-HIV integration and the health of slum populations, PLWHA and youth/adolescents, as well as to be involved in the "STEP UP" program to translate research to policy by communicating and disseminating research findings to key stakeholders (Population Council, Kenya)

\section{Malawi}

Grace Kumchulesi, Analyze longitudinal data from the Malawi Schooling and Adolescents Survey (MSAS) (Population Council, New York)

\section{The Americas}

\section{Brazil}

Weber Beringui Feitosa. Role of post-translational changes in the sperm proteome (Population Council, Center for Biomedical Research)

\section{Asia}

\section{Bangladesh}

Huraera Jabeen. Study adaptation to climate change and the roles of assets, gender dynamics and the built environment among the urban poor (Population Council, New York)

India

Aparajita Dasgupta. Conduct an evaluation of the National Rural Health Mission as a social safety net for young children in India (Population Council, New Delhi) 